\title{
Supporting Information: \\ Distinct Catalytic Behaviors between Two 1,4-Dioxane-Degrading Monooxygenases: Kinetics, Inhibition, and Substrate Range
}

Fei Li, Daiyong Deng, Mengyan Li*

Department of Chemistry and Environmental Science, New Jersey Institute of Technology,

Newark, NJ, USA 07102

*Address correspondence to Mengyan Li (mengyan.li@ njit.edu)

Phone: +1-973-642-7095

Fax: +1-973-596-3586 


\section{Materials and Methods}

\section{Gene Cloning and Plasmid Transformation}

The $4.0 \mathrm{~kb}$ fragment of the prmABCD gene cluster in $\mathrm{PH}-06$ was amplified with the forward primer 5'-AAGGAGATATACATATGACTGCATCGGTCACCACAC-3' and the reverse primer 5'-GTATGCGGCCGCCATGAAGCTTCACGCGGATACCGGGG-3', containing NdeI and HindIII sites (underlined), respectively. In parallel, the $4.3 \mathrm{~kb}$ fragment of the thmADBC gene cluster in $\mathrm{CB} 1190$ was amplified with the forward primer 5'AAGGAGATATACATATGACTGCCCCACCGATGAA-3' and reverse primer 5'GTATGCGGCCGCCATGGAATTCTACGACTCAGAGTTGATCAGCTCGAT-3', containing NdeI and EcoRI sites (underlined), respectively. Each $50 \mu \mathrm{L}$ of PCR reaction mixtures consisted of $1 \times$ PCR buffer, $100 \mathrm{nM}$ dNTPs, $250 \mathrm{nM}$ each primer, 1 unit of Pfu polymerase (Thermo, Carlsbad, CA), and $25 \mathrm{ng}$ of the genomic DNA of PH-06 or CB1190 as the template. Thermocycling conditions were: $98^{\circ} \mathrm{C}$ for $5 \mathrm{~min}$, then 30 cycles of $98^{\circ} \mathrm{C}$ for $20 \mathrm{~s}$ and $72^{\circ} \mathrm{C}$ for 6 min, and $72{ }^{\circ} \mathrm{C}$ for $10 \mathrm{~min}$ at the end. Amplicons with appropriate size were gel-purified using the Zymoclean $^{\mathrm{TM}}$ Gel DNA Recovery Kit (Zymo Research Corp, Irvine, CA).

PCR amplicon and vector pTip-QC2 were both digested with the designed enzyme (New England Biolabs, Ipswich, MA). After purification, the plasmid and PCR insert were ligated at a 1:3 (plasmid:insert) ratio at $16^{\circ} \mathrm{C}$ overnight with T4 DNA ligase (New England Biolabs, Ipswich, MA). The ligation mixture $(1 \mu \mathrm{L})$ was then used to transform electrocompetent E. coli DH5 $\alpha$ cells. Colonies with ampicillin $(50 \mu \mathrm{g} / \mathrm{mL})$ resistance were screened for appropriate recombinant constructs, which were designated as pTip-prmABCD and pTip-thmADBC, respectively. After purification with the Zyppy ${ }^{\mathrm{TM}}$ Plasmid Miniprep Kit (Zymo Research Corp, Irvine, CA), 50 ng of plasmid pTip-prmABCD, pTip-thmADBC, or empty vector pTip-QC2 was used to transform electrocompetent $\mathrm{mc}^{2}-155$ cells using the method as described in Ly et al. ${ }^{1}$ Electroporation was conducted at $1.8 \mathrm{kV} / \mathrm{cm}$ for $4.5 \mathrm{~ms}$ by the MicroPulser ${ }^{\mathrm{TM}}$ Electroporator (Bio-Rad, Hercules, CA). Successful transformants were selected on LB plates with ampicillin $(50 \mu \mathrm{g} / \mathrm{mL})$ after incubation at $30^{\circ} \mathrm{C}$ for 2 days.

\section{Culturing and Induction of Transformants}

Single colonies of $\mathrm{mc}^{2}-155$ containing the plasmid pTip-QC2 constructs with and without the $\operatorname{prm} A B C D$ or thm $A D B C$ insert, designated as $\mathrm{mc}^{2}-155$ (pTip-QC2), $\mathrm{mc}^{2}-155$ (pTip-prmABCD) and $\mathrm{mc}^{2}-155$ (pTip-QC2), respectively, were inoculated in $5 \mathrm{~mL}$ of $\mathrm{LB}$ broth dosed with chloramphenicol $(34 \mu \mathrm{g} / \mathrm{mL})$ and grown at $30^{\circ} \mathrm{C}$ while being shaken at $150 \mathrm{rpm}$. After the initial growth for $48 \mathrm{~h}$, cell culture $(5 \mathrm{~mL})$ was then inoculated to a 1-L flask containing $0.2 \mathrm{~L}$ of $\mathrm{LB}$ broth with chloramphenicol. In addition, $0.1 \%(\mathrm{v} / \mathrm{v})$ of Tween-80 were added to prevent the formation of cell aggregates during growth ${ }^{2}$. Cells were further incubated at $30{ }^{\circ} \mathrm{C}$ while being shaken at $175 \mathrm{rpm}$ until an OD600 of 0.6 was reached. Then, thiostrepton (EMD Millipore, Billerica, MA) in DMSO was added to a final concentration of $1 \mu \mathrm{g} / \mathrm{mL}$ to induce the heterologous expression. Induced cultures were incubated for a further $48 \mathrm{~h}$. Cells were harvested and the pellets were washed twice with $40 \mathrm{~mL}$ of ice-cold phosphate buffered saline (PBS) (20 mM sodium phosphate, $\mathrm{pH} 7.0,0.1 \%$ Tween-80) prior to the degradation assays. 


\section{Reverse Transcription Quantitative PCR (RT-qPCR)}

After induction with thiostrepton, total RNA of $\mathrm{mc}^{2}-155$ (pTip-prmABCD), $\mathrm{mc}^{2}-155$ (pTipthmADBC), and $\mathrm{mc}^{2}-155$ (pTip-QC2) transformants was extracted using PureLink ${ }^{\mathrm{TM}}$ RNA Mini Kit coupled with PureLink ${ }^{\mathrm{TM}}$ DNase Set (Thermo, Carlsbad, CA) to eliminate DNA contamination. The RNA extracts were converted to cDNA using the High-Capacity cDNA Reverse Transcription Kit (Thermo, Foster City, CA). Concentrations of synthesized cDNA were measured by SpectraMax Plus 384 Microplate Reader equipped with a SpectraDrop Micro-Volume Microplate (Molecular Devices, Sunnyvale, CA) and subsequently diluted to $5 \mathrm{ng} / \mu \mathrm{L}$ with nuclease-free water for further qPCR analysis. qPCR reaction $(20 \mu \mathrm{L})$ consisted of $2 \mu \mathrm{L}$ diluted cDNA, $10 \mu \mathrm{L}$ of $2 \times$ SYBR Green PCR master mix (Thermo, Foster City, CA), $0.2 \mu \mathrm{M}$ of each forward and reverse primer, and DNA-free water to a total volume of $20 \mu \mathrm{L}$. The primers were designed by $\mathrm{He}$ et al. ${ }^{3}$ and Li et al. ${ }^{4}$ for $p r m A$ and thmA quantification. RT-qPCR was conducted using QuantStudio ${ }^{\mathrm{TM}} 3$ Real-Time System (Thermo, Carlsbad, CA) with the following temperature setup: $95{ }^{\circ} \mathrm{C}$ for 10 min and 40 cycles of $95^{\circ} \mathrm{C}$ for $15 \mathrm{~s}$ and $60{ }^{\circ} \mathrm{C}$ for $1 \mathrm{~min}$. The copy numbers of target genes were quantified using standard curves prepared with serial dilution of genomic DNA of CB1190 and $\mathrm{PH}-06$. The expression levels of PRM and THM were defined as copy numbers of expressed prmA or thmA over a unit milligram of protein extracted from the induced transformants.

\section{Enzyme Kinetics Modeling}

Dioxane degradation kinetics were well described by the Michaelis-Menten equation (S1). Parameters for chlorinated solvent inhibition were estimated using equations (S2), (S3), and (S4) ${ }^{5}$, respectively.

Michaelis-Menten equation: $v_{0}=\frac{V_{\max }[S]}{K_{m}+[S]}$

Competitive inhibition: $v_{0}=\frac{V_{\max }}{1+\frac{K_{m}}{[S]}\left(1+\frac{[I]}{K_{I C}}\right)}$

Uncompetitive inhibition: $v_{0}=\frac{V_{\max }}{1+\frac{[I]}{K_{I U}}+\frac{K_{m}}{[S]}}$

Noncompetitive inhibition: $v_{0}=\frac{V_{\max }}{\left(1+\frac{[I]}{K_{I N}}\right)+\left(1+\frac{K_{m}}{[S]}\right)}$

As experiment had verified the trend of $K_{m}^{a p p}$ and $V_{\max }^{a p p}$, they can be transformed to the following format accordingly (Equation S5-S7):

Competitive inhibition: $K_{m}^{a p p}=K_{m}\left(1+\frac{[I]}{K_{I C}}\right)$

Uncompetitive inhibition: $K_{m}^{a p p}=K_{m} /\left(1+\frac{[I]}{K_{I U}}\right)$ and $V_{\max }^{a p p}=V_{\max } /\left(1+\frac{[I]}{K_{I U}}\right)$

Noncompetitive inhibition: $V_{\max }^{a p p}=V_{\max } /\left(1+\frac{[I]}{K_{I N}}\right)$ 
Where $\mathrm{K}_{\mathrm{m}}$ is the half saturation coefficient; $\mathrm{V}_{\max }$ denotes the maximum degradation rate; app means the apparent value based on our experiments; [S] and [I] represent the concentrations of substrate and inhibitor; $\mathrm{K}_{\mathrm{IC}}, \mathrm{K}_{\mathrm{IN}}$, and $\mathrm{K}_{\mathrm{IU}}$ are competitive, uncompetitive, and noncompetitive inhibition constants, respectively. To estimate the inhibition constant $\mathrm{K}_{\mathrm{I}}$ of each model, equations (S5), (S6) and (S7) can be linearized as follows ${ }^{6,7}$ :

Competitive Inhibition: $\frac{K_{m}^{a p p}}{V_{\max }^{a p p}}=\frac{K_{m}}{V_{\max }}+\frac{K_{m}}{V_{\max } K_{I C}}[I]$

Uncompetitive Inhibition: $\frac{1}{V_{\max }^{a p p}}=\frac{1}{V_{\max }}+\frac{1}{V_{\max } K_{I U}}[I] \& \frac{1}{K_{m}^{a p p}}=\frac{1}{K_{m}}+\frac{1}{K_{m} K_{I U}}[I]$

Noncompetitive Inhibition: $\frac{1}{V_{\max }^{a p p}}=\frac{1}{V_{\max }}+\frac{1}{V_{\max } K_{I N}}[I]$

Therefore, $\mathrm{K}_{\mathrm{I}}$ can be computed by the intercept divided by the slope of the regression line drawn by [I] against $K_{m}^{a p p} / V_{\max }^{a p p}, 1 / V_{\max }^{a p p}$, or $1 / K_{m}^{a p p}$. The experimental data with different concentrations of inhibitors and dioxane were fitted to three possible inhibition models for $\mathrm{K}_{\mathrm{IC}}$, $\mathrm{K}_{\mathrm{IN}}$, and $\mathrm{K}_{\mathrm{IU}}$ estimation. The most appropriate model was selected on the basis of the best fitness with the highest $\mathrm{R}^{2}$ (coefficient of determination).

\section{Analytical Approaches}

The total protein content of cells was used to quantify the bacterial biomass by Bradford Assay $^{8,9}$. Serial dilution of bovine serum albumin (BSA) (Thermo Scientific, Rockford, IL) was made to prepare a linear standard curve for the total protein measurement. The spectral absorbance at $660 \mathrm{~nm}$ was measured using the SpectraMax Plus 384 Microplate Reader (Molecular Devices, Sunnyvale, CA).

Dioxane concentration (> $1.0 \mathrm{mg} / \mathrm{L}$ ) was detected by GC-FID (Trace 1300, Thermo, Waltham, MA) coupled with a TG-BOND Q capillary column $(30 \mathrm{~m}$ length $\times 0.32 \mathrm{~mm}$ ID $\times 10$ $\mu \mathrm{m}$ film). Direct injection volume of filtered aqueous sample was $1 \mu \mathrm{L}$. Helium was used as the carrier gas with a constant flow rate of $6.0 \mathrm{~mL} / \mathrm{min}$. The inlet temperature was set as $200{ }^{\circ} \mathrm{C}$, and samples were split at the ratio of $2: 1$ by the split flow of $12 \mathrm{~mL} / \mathrm{min}$. The oven temperature started from $110{ }^{\circ} \mathrm{C}$ for $1 \mathrm{~min}$, then ramped to $180{ }^{\circ} \mathrm{C}$ at the rate of $15^{\circ} \mathrm{C} / \mathrm{min}$, and held for $4 \mathrm{~min}$. The detector temperature was maintained at $250^{\circ} \mathrm{C}$.

For samples with relatively low dioxane concentration $(<1.0 \mathrm{mg} / \mathrm{L})$, dioxane in the aqueous phase was extracted by the frozen micro-extraction (FME) method ${ }^{10}$, with dioxane- $\mathrm{d}_{8}$ and THF- $\mathrm{d}_{8}$ used as the surrogate and internal standard, respectively. Chemical separation was achieved by a TG-5MS column $(30 \mathrm{~m} \times 0.25 \mathrm{~mm} \times 0.25 \mu \mathrm{m})$ with a constant helium flow at 1.5 $\mathrm{mL} / \mathrm{min}$. The inlet temperature of $\mathrm{GC}$ was set at $250{ }^{\circ} \mathrm{C}$. The oven temperature program was set initially at $40{ }^{\circ} \mathrm{C}$ for $2 \mathrm{~min}$, increased to $150{ }^{\circ} \mathrm{C}$ at $10^{\circ} \mathrm{C} / \mathrm{min}$. Select ion monitoring (SIM) mode was employed to obtain the fingerprint ions of $\mathrm{m} / \mathrm{z} 58,96$ and 80, which were used to represent the ion abundance of dioxane, dioxane- $\mathrm{d}_{8}$ and THF- $\mathrm{d}_{8}$, respectively. The retention time of dioxane, dioxane- $\mathrm{d}_{8}$, and THF- $\mathrm{d}_{8}$ were $3.66,3.74$, and 2.45 minutes, respectively. 
Table S1. Estimated dioxane biodegradation kinetic parameters for transformants expressing PRM and THM in comparison with wild type PH-06 and CB1190.

\begin{tabular}{|c|c|c|c|c|}
\hline Strain & Model & $\mathrm{K}_{\mathrm{m}}(\mathrm{mg} / \mathrm{L})$ & $V_{\max }(\mathrm{mg} / \mathrm{h} / \mathrm{mg})$ & Reference \\
\hline $\mathrm{PRM}^{\mathrm{a}}$ & Michaelis-Menten & $53.0 \pm 13.1$ & $0.040 \pm 0.003$ & This study \\
\hline $\mathrm{THM}^{\mathrm{a}}$ & Michaelis-Menten & $235.8 \pm 61.6$ & $0.055 \pm 0.007$ & This study \\
\hline PH-06 & Michaelis-Menten & $78 \pm 10$ & / & He et al. ${ }^{3}$ \\
\hline CB1190 & Michaelis-Menten & $145 \pm 17$ & / & He et al. ${ }^{3}$ \\
\hline CB1190 & Michaelis-Menten & $160 \pm 44$ & $0.100 \pm 0.008$ & $\begin{array}{l}\text { Mahendra } \\
\text { et al. }{ }^{8}\end{array}$ \\
\hline CB1190 & Monod Model & $6.3 \pm 0.2^{b}$ & $0.11 \pm 0.00^{c}$ & $\begin{array}{l}\text { Barajas- } \\
\text { Rodriguez } \\
\text { et al. }^{11}\end{array}$ \\
\hline CB1190 & Michaelis-Menten & $63.36 \pm 20.24$ & $0.062 \pm 0.007$ & $\begin{array}{l}\text { Mahendra } \\
\text { et al. } .^{5}\end{array}$ \\
\hline CB1190 & Michaelis-Menten & 12.17 & 0.085 & $\begin{array}{l}\text { Zhang et } \\
\text { al. }^{12}\end{array}$ \\
\hline
\end{tabular}

${ }^{a}$ PRM and THM represent the transformant cells $\mathrm{mc}^{2}-155$ (pTip-prmABCD) and $\mathrm{mc}^{2}-155$ (pTipthmADBC), respectively.

${ }^{\mathrm{b}}$ Data converted from $\mathrm{mg} \mathrm{COD} / \mathrm{L}$ based on the theoretical oxygen demand of dioxane $(1.82 \mathrm{mg}$ $\mathrm{COD} / \mathrm{mg}$ 1,4-dioxane).

${ }^{c}$ Data converted from $\mathrm{mg}$ dioxane $\mathrm{COD} / \mathrm{mg}$ biomass COD/d based on the theoretical oxygen demand of dioxane, and bacterial formula of $\mathrm{C}_{5} \mathrm{H}_{7} \mathrm{O}_{2} \mathrm{~N}$. The protein percentage of bacterial cell is estimated as $65 \%$. 
Table S2. GC-FID or GC-MS analysis of tested substrates.

\begin{tabular}{|c|c|c|c|c|}
\hline Substrate & $\begin{array}{c}\begin{array}{c}\text { Molecular weight } \\
(\mathrm{g} / \mathrm{mol})\end{array} \\
\end{array}$ & $\begin{array}{c}\text { Total molar } \\
(\mu \mathrm{mol})\end{array}$ & $\begin{array}{c}\text { Retention } \\
\text { time (min) }\end{array}$ & $\begin{array}{l}\text { Selected } \\
\text { ion }(\mathrm{m} / \mathrm{z})\end{array}$ \\
\hline \multicolumn{5}{|c|}{ Ethers/Analogs } \\
\hline Dioxane & 88.11 & 5 & 7.9 & \\
\hline Tetrahydrofuran & 72.11 & 5 & 5.7 & GC/FID \\
\hline MTBE & 88.15 & 5 & 11.1 & \\
\hline Cyclohexane & 84.16 & 5 & 2.7 & 84 \\
\hline \multicolumn{5}{|c|}{ Short-chain Alkanes/Alkene } \\
\hline Ethene & 28.05 & 5 & 1.7 & \\
\hline Ethane & 30.07 & 5 & 1.8 & \\
\hline Propane & 44.1 & 5 & 2.1 & GC/FID \\
\hline Butane & 58.12 & 5 & 3 & \\
\hline Isobutane & 58.12 & 5 & 2.8 & \\
\hline \multicolumn{5}{|c|}{ Aromatics } \\
\hline Benzene & 78.11 & 5 & 2.7 & 78 \\
\hline Toluene & 92.14 & 5 & 5.2 & 92 \\
\hline \multicolumn{5}{|c|}{ Chlorinated Aliphatic Hydrocarbons } \\
\hline $\mathrm{VC}$ & 62.5 & 0.2 & 1.3 & 62 \\
\hline 1,1-DCE & 96.94 & 0.2 & 1.6 & 96,61 \\
\hline cDCE & 96.95 & 0.2 & 2.1 & 96,61 \\
\hline $\mathrm{tDCE}$ & 96.95 & 0.2 & 1.8 & 96,61 \\
\hline $1,2-\mathrm{DCA}$ & 98.96 & 0.2 & 2.5 & Full scan \\
\hline TCE & 131.4 & 0.2 & 3.3 & 130,95 \\
\hline $1,1,1-\mathrm{TCA}$ & 133.4 & 0.2 & 2.5 & 96,61 \\
\hline
\end{tabular}


Table S3. Inhibition kinetic parameters for dioxane degradation by PRM and THM expressing transformants with the presence of three chlorinated compounds.

\begin{tabular}{|c|c|c|c|c|c|c|c|}
\hline \multirow{2}{*}{$\begin{array}{c}\text { Chlorinated } \\
\text { Solvent }\end{array}$} & \multirow{2}{*}{ Enzyme } & \multicolumn{2}{|c|}{ Competitive } & \multicolumn{2}{|c|}{ Noncompetitive } & \multicolumn{2}{|c|}{ Uncompetitive } \\
\hline & & $\mathrm{K}_{\mathrm{IC}}(\mathrm{mg} / \mathrm{L})$ & $\mathbf{R}^{2}$ & $\mathrm{~K}_{\mathrm{IN}}(\mathrm{mg} / \mathrm{L})$ & $\mathbf{R}^{2}$ & KIU (mg/L) & $\mathbf{R}^{2}$ \\
\hline \multirow{2}{*}{ 1,1-DCE } & PRM & 5.27 & 0.745 & 6.22 & $0.937 *$ & -19.20 & 0.216 \\
\hline & THM & 1.41 & 0.901 & 2.14 & $0.987 *$ & -10.00 & 0.172 \\
\hline \multirow{2}{*}{ TCE } & PRM & 5.23 & 0.919* & 18.43 & 0.857 & -13.00 & 0.800 \\
\hline & THM & 1.13 & $0.921 *$ & -22.48 & 0.053 & -3.06 & 0.599 \\
\hline \multirow{2}{*}{ 1,1,1-TCA } & PRM & 5.17 & 0.888 & 20.66 & $0.940 *$ & -15.15 & 0.747 \\
\hline & THM & 2.06 & 0.951 & 1.72 & $0.957 *$ & 44.00 & 0.054 \\
\hline
\end{tabular}

*The inhibition model exhibiting the highest $\mathrm{R}^{2}$ value was selected with the best fitness. 
Table S4. Inhibition constants of chlorinated solvents to THM expressing transformants in comparison with CB1190.

\begin{tabular}{ccccc}
\hline Inhibitor & Inhibition model & $\mathbf{K}_{\mathbf{I}}(\mathbf{m g} / \mathbf{L})$ & $\mathbf{R}^{\mathbf{2}}$ & Reference \\
\hline \multirow{3}{*}{ 1,1-DCE } & Noncompetitive & 2.14 & 0.987 & this study \\
& Noncompetitive & $3.3 \pm 2.9$ & 0.95 & Mahendra et al. $^{5}$ \\
& Uncompetitive & $1.51 \pm 0.26$ & 0.978 & Zhang et al. $^{12}$ \\
\hline \multirow{2}{*}{ TCE } & Competitive & 1.13 & 0.921 & this study $^{12}$ \\
& Uncompetitive & $8.60 \pm 1.74$ & 0.974 & Zhang et al. $^{12}$ \\
\hline \multirow{2}{*}{$1,1,1-\mathrm{TCA}$} & Noncompetitive & 1.72 & 0.957 & this study $^{5}$ \\
& Noncompetitive & $1.2 \pm 1.0$ & 0.93 & Mahendra et al. \\
\hline
\end{tabular}


Table S5. Abiotic and biotic loss of selected substrates observed in abiotic control and treatment prepared with $\mathrm{mc}^{2}-155$ cells carrying the empty vector, respectively.

Substrate

Abiotic loss rate $(\mu \mathrm{mol} / \mathrm{h})$

Biotic loss rate $(\mu \mathrm{mol} / \mathrm{h} / \mathrm{mg})$

\begin{tabular}{rcc}
\hline & \multicolumn{1}{c}{ Ethers/Analogs } & - \\
\hline Dioxane & - & - \\
THF & - & - \\
Cyclohexane & - & $0.088 \pm 0.007$ \\
MTBE & $0.030 \pm 0.001$ & - \\
\hline & Short-chain Alkanes/Alkene & - \\
\hline Ethene & - & - \\
Ethane & - & - \\
Propane & - & - \\
Butane & - & \\
Isobutane & - & $0.054 \pm 0.001$ \\
\hline Benzene & - & Aromatics \\
Toluene & - & $0.070 \pm 0.005$ \\
\hline
\end{tabular}

Chlorinated aliphatic hydrocarbons

\begin{tabular}{rll}
\hline $\mathrm{VC}$ & - & - \\
$1,1-\mathrm{DCE}$ & - & - \\
$\mathrm{CDCE}$ & - & - \\
$\mathrm{tDCE}$ & - & - \\
$1,2-\mathrm{DCA}$ & - & - \\
$\mathrm{TCE}$ & - & - \\
$1,1,1-\mathrm{TCA}$ & - & - \\
\hline
\end{tabular}

- denotes the insignificant difference in concentrations measured at time 0 and $4 \mathrm{~h}$, respectively. Removal rates were calculated as the concentration difference in the first $4 \mathrm{~h}$ contact time normalized to the total protein (if any). 


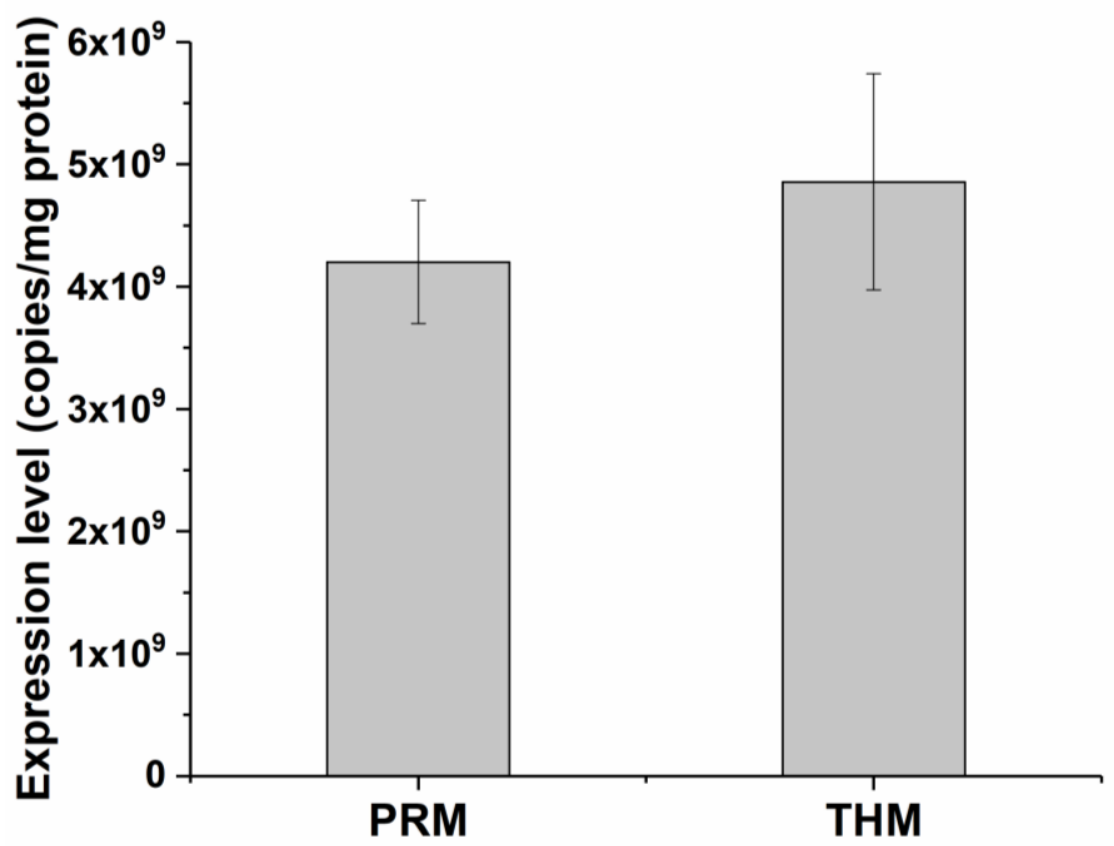

Figure S1. RT-qPCR analysis revealed uniform expression in $\mathrm{mc}^{2}-155$ (pTips-prmABCD) and $\mathrm{mc}^{2}-155$ (pTips-thmADBC) after induction. 


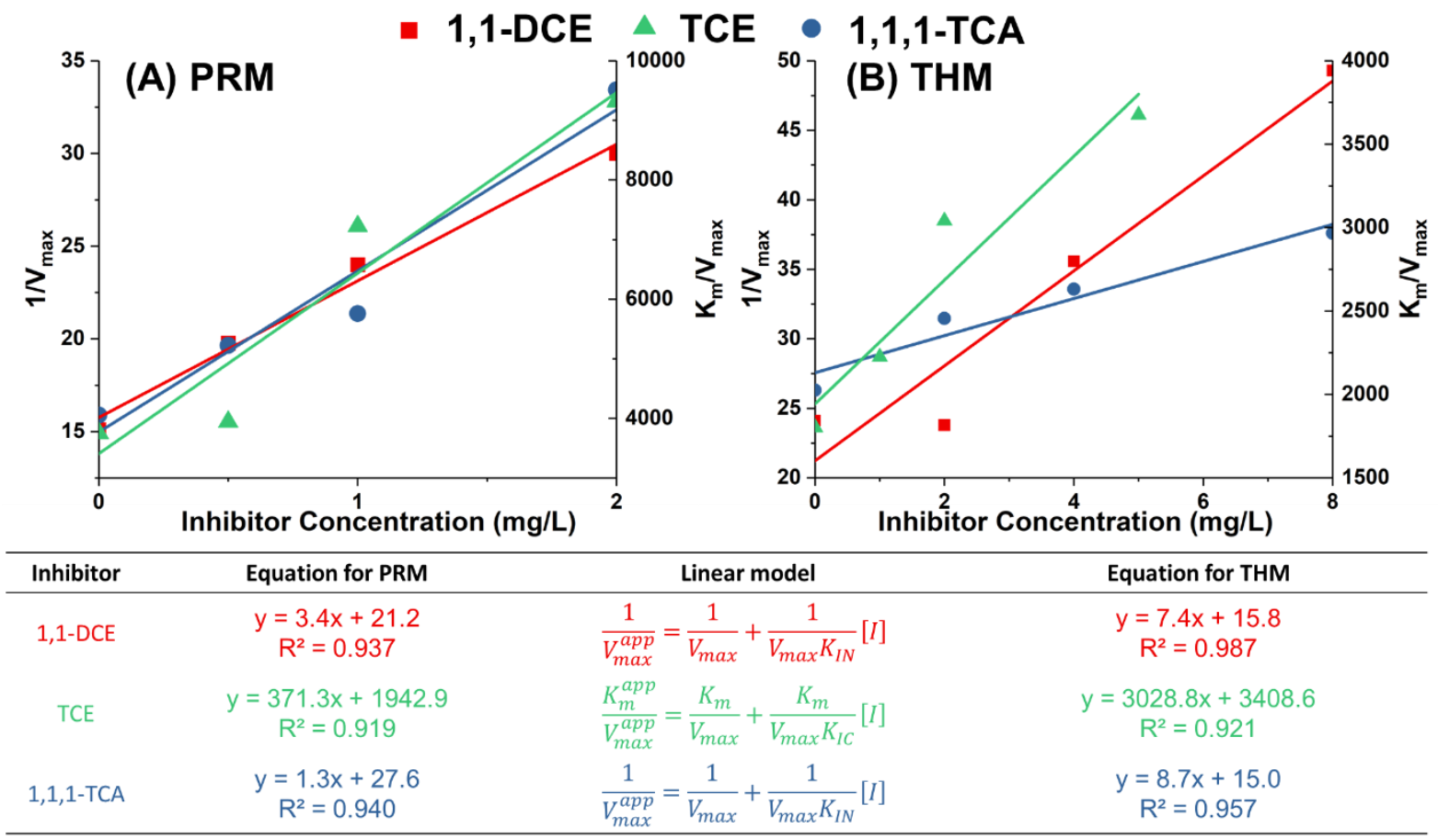

Figure S2. Regression between the apparent $\mathrm{V}_{\max }$ and $\mathrm{K}_{\mathrm{m}}$ values versus the concentrations of inhibitors fitted by the linearized inhibition model with the highest $R^{2}$ value. 


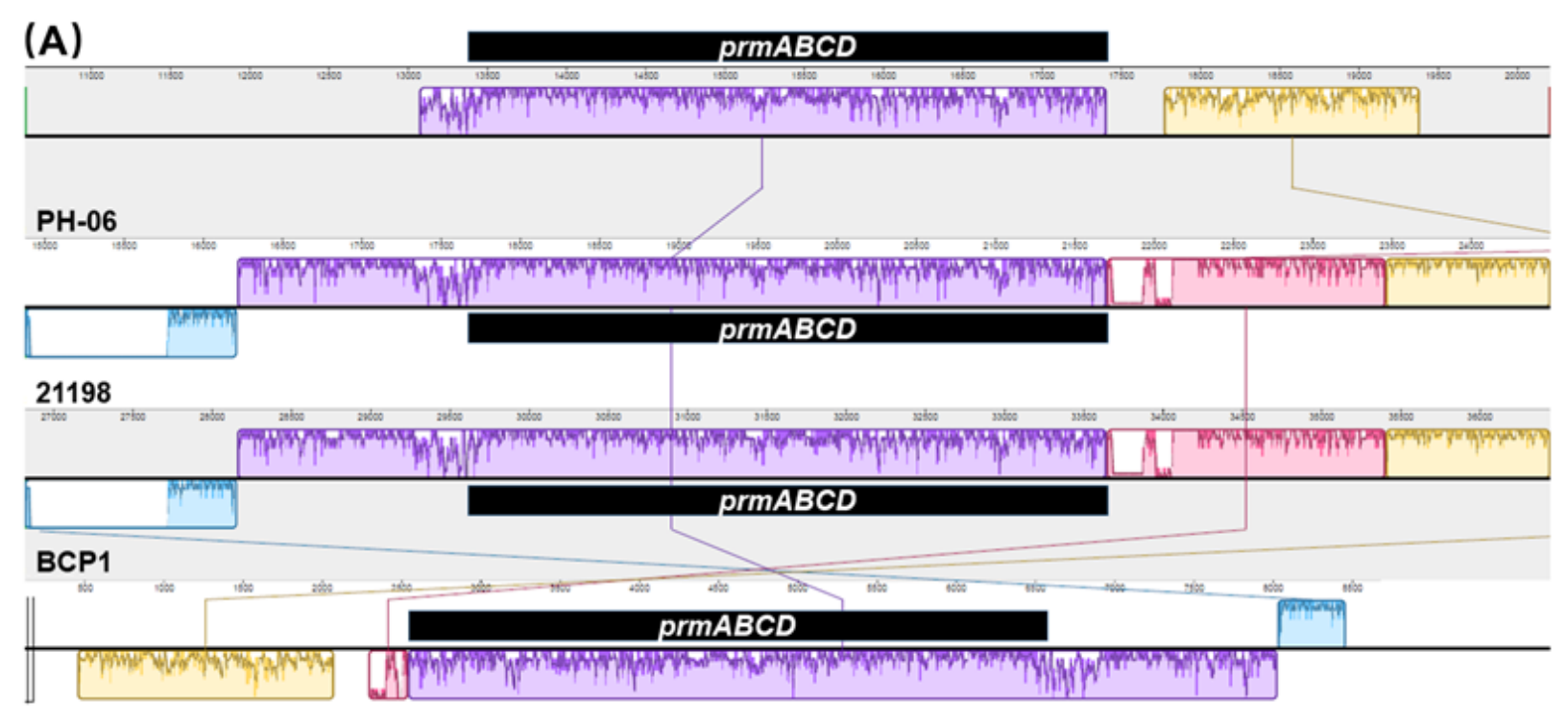

ENV421

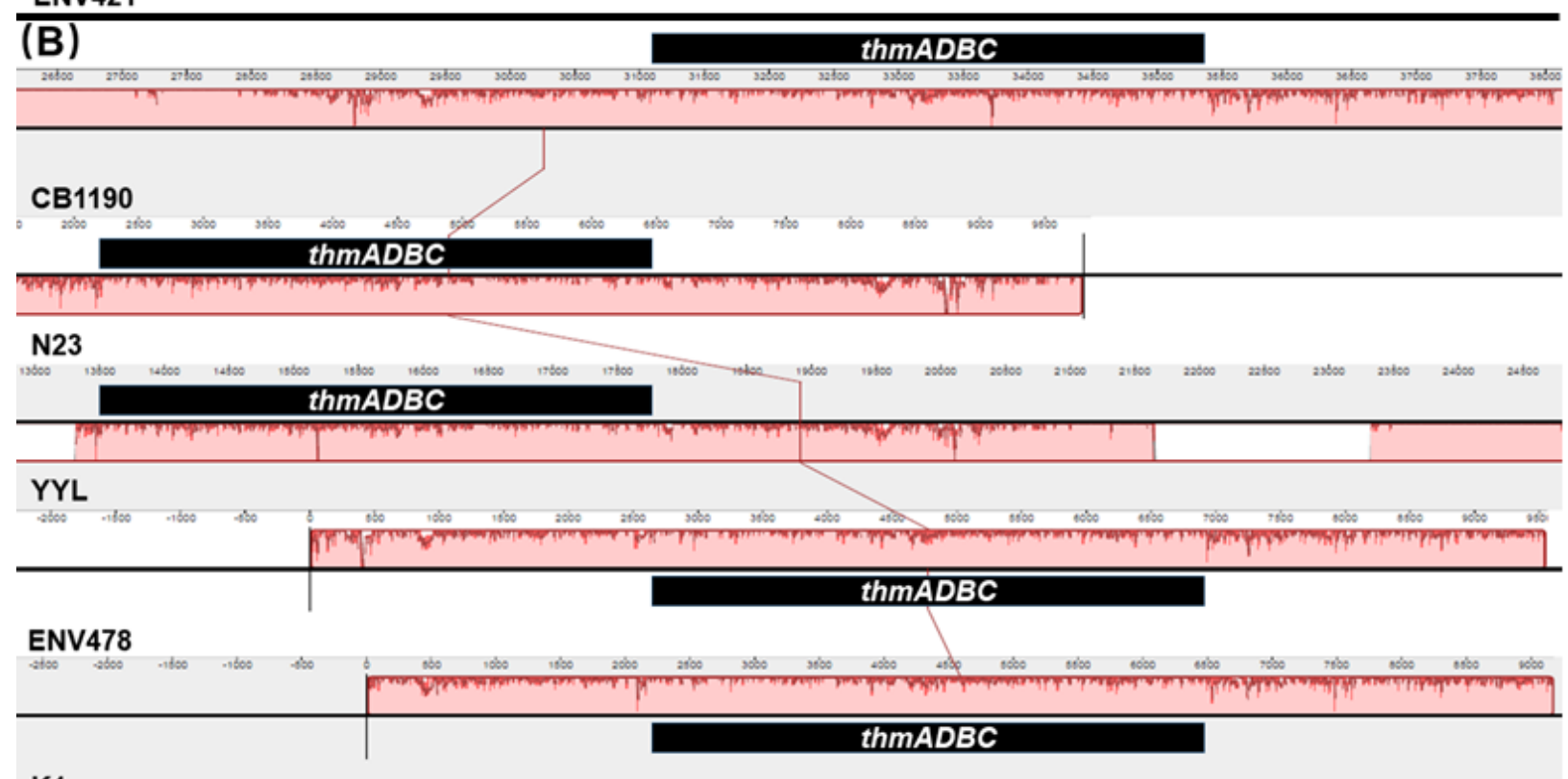

K1

Figure S3. Alignment of the nucleotide sequences of (A) five $\operatorname{prm} A B C D$ gene clusters and (B) five thm $A D B C$ gene clusters from different Actinomycetes generated by Mauve 2.4.0. The prmABCD or thm $A D B C$ gene clusters are indicated by the black bars. The Locally Collinear Blocks (LCB) indicate regions of homology among all five strains; the similarity profiles of the genome sequences are denoted by colored line inside blocks. The blocks depicted above or below the centre line indicate the location of the transcription strand in the forward or inverse orientation. 


\section{References}

1. Ly, M. A.; Liew, E. F.; Le, N. B.; Coleman, N. V., Construction and evaluation of pMycoFos, a fosmid shuttle vector for Mycobacterium spp. with inducible gene expression and copy number control. Journal of microbiological methods 2011, 86, (3), 320-326.

2. Cheung, S.; McCarl, V.; Holmes, A. J.; Coleman, N. V.; Rutledge, P. J., Substrate range and enantioselectivity of epoxidation reactions mediated by the ethene-oxidising Mycobacterium strain NBB4. Applied microbiology and biotechnology 2013, 97, (3), 1131-1140.

3. He, Y.; Mathieu, J.; Yang, Y.; Yu, P.; da Silva, M. L.; Alvarez, P. J., 1, 4-Dioxane biodegradation by Mycobacterium dioxanotrophicus $\mathrm{PH}-06$ is associated with a group-6 soluble di-iron monooxygenase. Environmental Science \& Technology Letters 2017, 4, (11), 494-499. 4. Li, M.; Mathieu, J.; Liu, Y.; Van Orden, E. T.; Yang, Y.; Fiorenza, S.; Alvarez, P. J. J., The abundance of tetrahydrofuran/dioxane monooxygenase genes $(\mathrm{thmA} / \mathrm{dxmA})$ and 1,4-dioxane degradation activity are significantly correlated at various impacted aquifers. Environmental Science \& Technology Letters 2014, 1, (1), 122-127.

5. Mahendra, S.; Grostern, A.; Alvarez-Cohen, L., The impact of chlorinated solvent cocontaminants on the biodegradation kinetics of 1, 4-dioxane. Chemosphere 2013, 91, (1), 88-92.

6. $\quad$ Kim, Y.; Arp, D. J.; Semprini, L., Kinetic and inhibition studies for the aerobic cometabolism of 1,1,1- trichloroethane, 1, 1- dichloroethylene, and 1, 1- dichloroethane by a butane- grown mixed culture. Biotechnology and Bioengineering 2002, 80, (5), 498-508.

7. Kim, Y.; Arp, D. J.; Semprini, L., A combined method for determining inhibition type, kinetic parameters, and inhibition coefficients for aerobic cometabolism of 1, 1, 1trichloroethane by a butane- grown mixed culture. Biotechnology and bioengineering 2002, 77, (5), 564-576.

8. Mahendra, S.; Alvarez-Cohen, L., Kinetics of 1, 4-dioxane biodegradation by monooxygenase-expressing bacteria. Environmental Science \& Technology 2006, 40, (17), 54355442.

9. Deng, D.; Li, F.; Li, M., A novel propane monooxygenase initiating degradation of 1, 4dioxane by Mycobacterium dioxanotrophicus PH-06. Environmental Science \& Technology Letters 2017, 5, (2), 86-91.

10. Li, M.; Conlon, P.; Fiorenza, S.; Vitale, R. J.; Alvarez, P. J., Rapid analysis of 1, 4dioxane in groundwater by frozen micro- extraction with gas chromatography/mass spectrometry. Groundwater Monitoring \& Remediation 2011, 31, (4), 70-76.

11. Barajas-Rodriguez, F. J.; Freedman, D. L., Aerobic biodegradation kinetics for 1, 4dioxane under metabolic and cometabolic conditions. Journal of Hazardous Materials 2018, 350, 180-188.

12. Zhang, S.; Gedalanga, P. B.; Mahendra, S., Biodegradation kinetics of 1, 4-dioxane in chlorinated solvent mixtures. Environmental Science \& Technology 2016, 50, (17), 9599-9607. 